Egypt. J. Aquat. Biol. \& Fish. Vol.10, No.2: 117- 146 (2006) ISSN 1110-6131

\title{
IMPACT OF WATER QUALITY DETERIORATION ON CORAL REEF COMMUNITY STRUCTURE IN THE NORTHERN RED SEA, EGYPT
}

\author{
Abdel-Hamid A. M. Ali and Mohamed A. Hamed \\ National Institute of Oceanography and Fisheries, Suez, Egypt
}

Key words: water quality, corals, eutrophication, sea urchins, macroalgae, nutrients.

\begin{abstract}
Fifteen water quality parameters and nine coral community variables Fere assessed in eight reef sites along the Red Sea coast of Egypt. Coral reef environments are suffering of stress from increased anthropogenic activities, particularly in the vicinity of heavily populated and touristic areas such as Hurghada, Ain Al-Sukhna and Sharm ElSheikh. Increased terrestrial runoff of sediments, nutrients, organic matter and other pollutants are the main causes of water quality deterioration in the investigated reef sites. The results showed that bioerosion of corals by sea urchins, and enhanced abundance of macroalgae and consequent competitive overgrowth of corals were the major reasons of coral damage observed in the area of study. Population density of sea urchins exhibited significant and positive correlations with the majority of eutrophication parameters. Salinity was significantly and negatively correlated with live hard coral cover. Exceeding levels of DIN and TSM above the threshold concentrations for eutrophication were reported to be indirectly and adversely affecting coral reefs through stimulating the growth of macroalgae, enhancing sea urchin density and reducing water transparency. The results support the predictions of bottom-up hypothesis that confirm the critical role of eutrophication in structure of coral reef community.
\end{abstract}

\section{INTRODUCTION}

Coral reefs have often been described as fragile ecosystems in delicate balance with nature (Endean, 1976). Johannes (1975) argued that since corals had evolved in stable tropical environment subject to narrow fluctuations in physical and chemical variables, they should be specialized and therefore highly sensitive to man-induced pollutants. One 
goal of coral ecologists is to predict the effects of changing environmental conditions (natural or man-induced) on the integrity of coral reef. community. Coral reef environments are under increased stress from anthropogenic activities in the last two decades (Bryant et al., 1998), particularly those in the vicinity of land-based activities. Urbanization of coastal areas, sewage disposal and terrestrial sediment runoff, intensive construction of tourist units (tourist villages, hotels and recreational resorts), coastal development; construction of new roads and improving the old ones, runoff from tourist boats, traveling tankers and cargo vessels, and oil pollution are all increasing in the Northern Red Sea during the recent years. These activities are the main causes of water quality deterioration in the Red Sea (Ali, 2001). The coral reef literature contains many accounts of coral reef degradation associated with declining water quality (e.g. Smith et al., 1981; Tomascik and Sander, 1987a; Bell, 1991; Hunte and Wittenberg, 1992; Wittenberg and Hunte, 1992; Lapointe et al., 1993; Ferrier-Pages et al., 2000; Harrison and Ward, 2001; Koop et al.. 2001; Jompa and McCook, 2002; Lipp et al.. 2002; Webster and Smith, 2002; ISRS, 2004). The present study investigates the possible effects of water quality deterioration on coral reefs in the Northern Red Sea, with a special focus on the responses of coral community structure to eutrophication parameters.

\section{Water quality parameters:}

\section{MATERIALS AND METHODS}

Water samples were collected seasonally from eight locations in the Northern Red Sea (Figure 1), using Nisken's bottle. Water temperature, hydrogen ion concentration $(\mathrm{pH})$ and salinity were measured in situ, using CTD (YSI-6000). Samples for dissolved oxygen were fixed in the field and determined on the same day of collection, using the classical Winkler method (APHA 1995). Biological oxygen demand (BOD) and Chemical oxygen demand (COD) were analyzed, following the method described by APHA (1995). Transparency was measured using a white enameled Secchi disk. Samples for determinations of total suspended matter (TSM) were filtered through pre-washed, dried and pre-weighed $(0.45 \mu \mathrm{m})$ Millepore filters. The filters and their contents were dried at $60^{\circ} \mathrm{C}$ until constant weight. The differences in the dry weight of filters before and after filtration were expressed in $\mathrm{mg} \mathrm{I}^{-1}$ suspended matter (Parsons et al., 1984). Prior to analysis of dissolved inorganic nutrients, seawater samples were immediately filtered through $0.45 \mu \mathrm{m}$ Millipore filters, using 
vacuum pump to remove phytoplankton and other small organisms that rapidly reduce the nutrient concentrations in the samples. The concentrations of dissolved nitrite, nitrate, ammonia, reactive phospliate and reactive silicate were then determined spectrophotometerically, according to the analytical procedures described by Parsons ef al. (1984). The concentrations of dissolved nutrients are expressed as $\mu \mathrm{M}$.

For determination of Chlorophyll $a$, each 2-liter water sample was filtered, within 2 hours, through a $0.45 \mu \mathrm{m}$ Millipore filter, using vacuum pump, while adding 3-4 drops of $\mathrm{MgCO}_{3}$ suspension in the final phase of filtering as a preservative (to prevent acidity on the filter). Then the filter was dried under vacuum and kept in refrigerator until analysis for 18-24 hours. Chlorophyll $a$ in the phytoplankton cells retained on the filter was extracted using $90 \%$ acetone, centrifuged and the absorbance was measured spectrophotometrically at wavelengths $750,664,647$ and 630 nm (Parsons el al., 1984).

\section{Coral Community variables:}

Data collected using Belt quadrat method (Dodge et al., 1982). In this method, a transect lines were employed to act as guides along which $1 \mathrm{~m}^{2}$ quadrat was placed every meter continuously, or at regular intervals (usually $2 \mathrm{~m}$ apart) depending on the transect length and the reef profile. Transects were located parallel to each other and to the reef margin. The quadrat was made of aluminum pipe and divided into 100 squares with nylon line, each square therefore represented $1 \%$ of the quadrat.

The following attributes were recorded in each quadrat: total number of coral species; total number of colonies; abundance of each species; living coverage of each species (\%); living coverage of hard corals, soft corals and macroalgae (fleshy and turf algae); dead corals cover $(\%)$; population density of sea urchins ((\# of urchins $\left.\mathrm{m}^{-2}\right)$; Bare substratum (\%). These attributes were again calculated at the level of each reef site.

Species diversity was calculated, using Shannon \& Weaver's (1948) formula: $\mathrm{H}^{-}=-\sum \mathrm{P}_{\mathrm{i}} \ln \mathrm{P}_{\mathrm{i}}$.

Where $P i=n_{i} / N$ is the proportion of the total number of individuals $(N)$ belonging to the ith species $\left(n_{i}\right)$.

Pielou's (1966) evenness index $\left(\mathrm{I}^{\prime}\right)=\mathrm{H}^{\prime}$ (observed) $/ \mathrm{H}_{\max }$

Where $\mathrm{H}_{\max }=$ in $\mathrm{S}$ (total number of species) 


\section{RESULTS AND DISCUSSION}

Declining water quality due to terrestrial runoff not only affects coral population directly, but also has profound effects on other key groups of reef organisms. Establishing causal relationships between ecological responses and environmental conditions is often difficult. Nevertheless, the present study provides links between water quality parameters and some coral community indices.

\section{Hydrographic parameters:}

$\mathrm{pH}$ values were relatively stable along the investigated locations (Table 1) and fell in the normal range $(7.5-8.4)$ of reef waters (Rogers et al., 1994).

Table ( 1 ) showed that waters in the area of investigation are well oxygenated (Fahmy, 2000; EIMP, 2005) and the dissolved oxygen (DO) concentrations are adequate for coral survival and development (Rogers et al., 1994). The highest mean DO concentration $\left(8.76 \mathrm{mg} \mathrm{l}^{-1}\right)$ was recorded at location VIII, whereas the lowest value $\left(7.37 \mathrm{mg} \mathrm{l}^{-1}\right)$ was recorded at location I. The higher levels of DO at locations VIII (Dahab) and V (Ras Mohamed) reflected the high wave action and good water circulation, which enhance the exchange of gases at the sea-air interface, in addition to relatively low levels of water pollution in these areas.

The variation in salinity value is not great in the area of study because there are no large freshwater sources like rivers or drains that discharge into the sea. The maximum annual mean of salinity (41.78 ppt) was measured at location III (south Ain Al-Sukhna), while the minimum value $(40.07 \mathrm{ppt})$ was measured at location VII (Table 1). The relatively higher salinity level recorded at location III may be attributed to high evaporation rate and low wave action in this area, which is shallow and protected from the prevailing northerly winds by Attaqa mountain and the surrounding hills. The data in Table (2) showed also a general decrease in average salinity from Gulf of Suez towards Gulf of Aqaba. This can be a result of lower evaporation rate, higher wave action, greater depth range and good water circulation in the Gulf of Aqaba compared to Gulf of Suez (Fahmy, 2000; EIMP, 2004), in addition to dissolution of some evaporite beds from the bottom in the Gulf of Suez (Morcos, 1970; Beltagy, 1983). High salinity level (>41 ppt) is amongst the factors that cause a reduction in hard coral cover and species diversity, whereas little number of species can survive with increased salinity (Sheppard, 1988). This view is supported by the significant negative correlation $\left(r^{2}=0.6, t=\right.$ $-3.03, P<0.05)$ obtained between salinity and live hard coral cover as well 
as the moderate positive correlation $\left(r^{2}=0.33, t=1.73, \mathrm{P}>0.05\right)$ between salinity and dead coral cover (Table 4). Consequently, it is suggested that the relatively higher salinity reported at location III may act with other factors (e.g. increased terrestrial sediment runoff and pollution) in reducing hard coral cover and species diversity (Scheer, 1984), and increasing dead coral cover in this area (Table 2).

\section{Eutrophication parameters:}

\section{Chemical Oxygen Demand (COD):}

Since sewage discharge is a major source of organic matter in the area of study, COD is considered one of the sewage pollution indicators (Adams, 1990). Concentration of COD (Table 1) showed a trend of decline from Northern Red Sea proper (sites I and II) across Gulf of Suez (sites III and IV) towards Gulf of Aqaba (sites VII and VIII). Highest COD concentration ( $\left.2.16 \mathrm{mg} \mathrm{l}^{-1}\right)$ was reported at locations III and IV, while the lowest value (1.36 $\left.\mathrm{mg} \mathrm{l}^{-1}\right)$ occurred at location VII. The higher levels of COD in locations I, II, III and IV can be ascribed to the enhanced discharge of untreated domestic sewage associated with population growth in cities of Safaga, Hurghada, Suez and Al-Tur, in addition to the effluents of tourist villages and recreational resorts established in these areas. Ali (2001) recorded high percentages of organic matter in reef sediments at Ain Al-Sukhna (12.15\%), Hurghada $(5.12 \%)$ and Safaga $(5.21 \%)$.

In the present study, the moderate inverse relationship $\left(r^{2}=0.35, t=\right.$ $-1.81, \mathrm{P}>0.05$ ) obtained between COD concentration and live hard coral cover (Table 5) indicated the direct adverse effect of increased organic matter on coral community structure. On the other hand, COD concentration was significantly and positively correlated $\left(r^{2}=0.57, \mathrm{t}=\right.$ $2.82, \mathrm{P}<0.05$ ) with population density of sea urchins, demonstrating the indirect detrimental influence of increased organic matter on coral reefs. This may be because the sea urchins, particularly Diadema setosum and Echinometra mathaei are the main coral skeleton bioeroders and excavators in the area of investigation (Vine, 1986; Hutchings, 1986; Hodgson, 1999; Ali, 2001). Thus, the results revealed that the indirect effect of increased organic matter is more pronounced than direct effect. Smith et al. (1981), Kinsey (1988), as well as Bell and Elmetri (1995) have shown that sewage pollution, which is rich in organic matter, can also enhance the growth of filter-feeding animals such as ascidians, sponges and soft corals, which either outcompete corals or result in increased bioerosion via burrowing molluscs, sponges, sea urchins and 
polychaete worms. Higher levels of organic matter can also be implicated in reduction of transparency, which is necessary for increasing light penetration to coral's symbiotic attendant zooxanthellae to perform photosynthesis. This is indicated by the substantial inverse relationship $\left(r^{2}\right.$ $=0.44, \mathrm{t}=-2.18, \mathrm{P}>0.05$ ) between the transparency and COD (Table 3 ). Biological Oxygen Demand (BOD):

$\mathrm{BOD}$ is a way to assess the degree of sewage pollution in the area of investigation. High BOD from the sewage, possibly coupled with hydrogen sulfide generation and other pollutants, might also impose toxic effects on coral communities (Grigg and Dollar, 1990). BOD concentration in the present results (Table 1) followed the trend of COD, with the exception of its concentration at site VIII $\left(2.50 \mathrm{mg} \mathrm{I}^{-1}\right)$. The greatest mean concentration was measured at location III $\left(3.18 \mathrm{mg} \mathrm{l}^{-1}\right)$, whereas the smallest value was measured at location VII $\left(1.71 \mathrm{mg} \mathrm{l}^{-1}\right)$. The relatively elevated levels of BOD in locations III, I, II, VIII and IV reflected the increased discharge of untreated domestic sewage and wastewater from coastal cities and tourist urits in these areas. The range of annual average concentrations of BOD in the present study (1.71 $\left.3.18 \mathrm{mg} \mathrm{l}^{-1}\right)$ is much higher than that reported from reef areas in the west coast of Barbados, West Indies $\left(0.71-1.09 \mathrm{mg} \mathrm{l}^{-1}\right.$ ( Tomascik and Sander, 1985).

Tables 3 and 4 demonstrated that increased BOD concentrations were significantly associated with reduced transparency $\left(r^{2}=0.56, \mathrm{t}=\right.$ $2.75, \mathrm{P}<0.05)$ and enhanced population density of sea urchins $\left(r^{2}=0.54, \mathrm{t}\right.$ $=2.65, \mathrm{P}<0.05$ ). Thus, elevated levels of BOD can indirectly deteriorate the coral community through enhancing the population density of sea urchins (Diadema setosum and Echinometra mathaei, main coral bioeroders and excavators) and reducing the illumination required for photosynthesis, which is carried out by coral's endosymbiotic zooxanthellae, a vital source of energy needed for coral calcification and growth (Dodge and Vaisnys, 1977; Tomascik and Sander 1985; Rogers 1990). So, it is concluded that the higher concentrations of BOD may be involved in lowering the growth rates of reef-building corals and enhancing bioerosion of coral skeletons.

Total suspended matter (TSM) and transparency:

TSM and transparency were measured in this study to indicate the degree of water turbidity. Suspended particles in the water absorb and scatter light, reducing light penetration. TSM has been documented as one of the main environmental variables adversely affecting the growth of 
corals because it is involved in physical smothering of corals and reduction of coral calcification through attenuation of available light for zooxanthellae photosynthesis (Tomascik and Sander, 1985; Cortes and Risk, 1985; Wittenberg and Hunte, 1992). The reported threshold concentration of TSM for coral reef environment is generally less than 5 $\mathrm{mg} \mathrm{l}^{-1}$ and hence the reef is considered disturbed when the concentration of TSM is greater than $5 \mathrm{mg} \mathrm{l}^{-\mathrm{l}}$ (Cortes and Risk, 1985). Consequently, the levels of TSM recorded in the water column of the sampling locations (Table I) were higher than critical threshold levels. Locations III and II had greater concentrations of TSM (8.17 and $8.1 \mathrm{mg} \mathrm{l}^{-1}$, respectively) and lower levels of transparency $(6.0$ and $7.0 \mathrm{~m}$, respectively, Table 1). Conversely, locations IV and VII exhibited the lower concentrations of TSM (5.22 and $5.56 \mathrm{mg} \mathrm{l}^{-1}$, respectively) and higher levels of transparency (11.5 and $11.4 \mathrm{~m}$, respectively). The higher significant negative correlation $\left(r^{2}=0.86, \mathrm{t}=-6.05, \mathrm{P}<0.001\right.$, Table 2) obtained between TSM and transparency indicated the exclusive role of TSM in reducing of transparency and the two variables were strongly antagonistic. Concentrations of TSM tend to be lowered towards southeast of Gulf of Suez (sites IV, V and VI) and Gulf of Agaba (sites VII and VII), whereas transparency showed the opposite trend (Table 1). The mean concentration of TSM in the present study $\left(6.57 \mathrm{mg} \mathrm{l}^{-1}\right)$ is higher than that reported by Tomasck and Sander (1985) in the west coast of Barbados, West Indies (5.89 $\left.\mathrm{mg} \mathrm{l}^{-1}\right)$ and by Cortes and Risk (1985) at Cahuita reef, Costa Rica (4.84 $\mathrm{mg}^{-1}$ ).

Higher concentrations of TSM recorded at Locations III (south Ain Al-Sukhna) and II (Hurghada) were probably a direct result of enhanced terrestrial input of sediments, untreated sewage and wastewaters concomitant with increased coastal urbanization and expansion of touristic activities. Higher levels of phytoplankton biomass (measured as chlorophyll $a$ concentration) determined at locations II and III (Table 1) could also contribute to TSM increment in theses areas (Bell and Elmetri, 1995; Genin et al., 1995; Lapointe and Thacker, 2002). This contribution was corroborated by the significant positive correlation $\left(\left(r^{2}=0.54, t=\right.\right.$ $2.68, \mathrm{P}<0.05$ ) established between Chlorophyll $a$ concentration and TSM (Table 3).

Table ( 5 ) shows that live hard coral cover was significantly increased $\left(r^{2}=0.54, \mathrm{t}=2.67, \mathrm{P}<0.05\right)$ with increment of transparency and considerably declined $\left(r^{2}=0.41, t=-2.05, \mathrm{P}>0.05\right)$ with elevated concentrations of TSM. This confirms the important role of transparency 
in increasing coral calcification and growth rates through enhancing the amount of light available for zooxanthellae photosynthesis (Rogers, 1979; Cortes and Risk, 1985; Tomascick and Sander, 1985). The higher levels of transparency recorded at sites VII and VIII (Table 1) may partially explain the greater live hard coral covers determined in these areas $(63.55$ and $67.1 \%$, respectively, Table 2). Previous studies (e.g. Tomascik and Sander, 1987a; Edinger et al., 1998; van Woesik et al., 1999; Ali, 2001) reported that high turbidity, shading and high particle loads lead to reduced biodiversity in hard corals and octocorals due to their differences in tolerance levels.

TSM concentration was significantly and positively $\left(r^{2}=0.53, t=\right.$ $2.58, \mathrm{P}<0.05$ ) correlated with the population density of sea urchins (Table 4) reflecting the indirect destructive effect of increased TSM on reefbuilding corals. This may be attributed to the fact that higher concentration of organic matter suspended in the water column satisfies the additional food need of sea urchins (Smith et al., 1981).

\section{Nutrients:}

Coral reefs are typically occurring in waters that contain low levels of inorganic nutrients (Lewis, 1977). The threshold concentrations of dissolved inorganic nutrients, above which the decline of coral reef from eutrophication begins to occur, are $1.0 \mu \mathrm{M}$ for dissolved inorganic nitrogen (DIN), $0.1-0.5 \mu \mathrm{M}$ for nitrate, $0.2-0.5 \mu \mathrm{M}$ for ammonium, and less than $0.3 \mu \mathrm{M}$ for soluble reactive phosphorus (Furnas, 1991; Bell. 1992; Lapointe et al., 1993). So, the coral reefs are particularly susceptible to nutrient enrichment due to these very low threshold levels. The average concentrations of soluble reactive phosphate in the present results (Table 1) were very low, ranging from 0.01 to $0.06 \mu \mathrm{M}$, and below the threshold levels $(<0.3 \mu \mathrm{M})$ in all locations and detectable limit $(<0.03$ $\mu \mathrm{M}$, Fahmy, 2001) in locations V, VI, VII and VIII. Therefore, soluble reactive phosphate concentrations were excluded from explanation.

The annual average concentrations of nitrite were also very low: ranging from $0.03 \mu \mathrm{M}$ at location VII to $0.28 \mu \mathrm{M}$ at location III (Table 1). Nitrite is the unstable compound of inorganic nitrogen forms because of its intermediate position in oxidation-reduction processes between nitrate and ammonium. The average concentrations of nitrate recorded at locations III, IV, V, VI and VII exceeded the critical threshold range (0.1$0.5 \mu \mathrm{M})$ for eutrophication, while the average concentrations of ammonia were above the threshold range $(0.2-0.5 \mu \mathrm{M})$ in all locations with the exception of location VIII (Table 1). Dissolved inorganic nitrogen (DIN) 
is the summation of dissolved ammonia, nitrite and nitrate. Average concentration of DIN was lower than the critical threshold $(1.0 \mu \mathrm{M})$ only at locations I and VIII, whereas the average concentrations at the remaining locations exceeded the eutrophication threshold level (Table 1). Table 1 showed also that the nitrate was the dominant inorganic nitrogen species at site III, while ammonia was the dominant inorganic nitrogen species at sites II and VI. Sewage pollution and terrestrial sediment runoff are the principal sources of dissolved inorganic nitrogen compounds in the area of investigation (Riegl and Velimirov, 1991; EIMP, 2004). The higher levels of DIN and ammonia recorded at locations II and VI, as well as the elevated levels of DIN and nitrate recorded at location III may be attributed to the fact that these areas are the main touristic and recreational centers in the Egyptian Red Sea, in addition to the rapid growth of coastal cities, particularly Hurghada (site II) and Sharm elSheikh (site VI). These factors increased the terrestrial dumping of sewage, wastewater and sediments in the adjacent reef areas.

Reactive silicate is a good indicator of freshwater dispersion and of the potential for diatom blooms. The highest mean concentration of reactive silicate $(4.07 \mu \mathrm{M})$ was registered at site III, whereas the lowest value $(0.98 \mu \mathrm{M})$ was at site VII (Table 1). Sewage disposal, vertical mixing, solution of diatoms, partial dissolution of quartz and clay particles transported to the sea with terrestrial runoff are considered the major factors controlling the distribution of silicate in the Northern Red Sea (Fahmy, 2001; EIMP, 2004). The highest concentration of silicate obtained at location II (south Ain Al-Sukhna) was probably due to the increased terrestrial runoff, associated with construction activities and coastal development, in particular widening and improving the coastal way between Suez and Hurghada. The freshwater discharged with sewage from recreational resorts could contribute to the raised silicate concentration at site III. The significant positive correlations attained between reactive silicate and both nitrate $\left(r^{2}=0.63, t=3.21, \mathrm{P}<0.05\right)$ and DIN $\left(r^{2}=0.51, \mathrm{t}=2.5, \mathrm{P}<0.05\right)$ indicated that they are relatively derived from related sources.

The present data (Table 4) suggested that elevated nutrient concentrations resulted in a range of indirect impacts on coral communities and under extreme situations, can result in coral community collapse (Smith et al., 1981; Pastorak and Bilyard, 1985; ISRS, 2004). One of the indirect detrimental effects of nutrient enrichment, associated with enhanced terrestrial runoff, is the dense population of sea urchins 
(regular echinoids), which are commonly reported as the main cause of corals bioerosion (Bak, 1994). This view is supported by the higher sea urchin density (Echinometra mathaei and Diadema setosum) at locations IIl and II (7.9 and 4.77 urchins $\mathrm{m}^{-2}$, respectively, Table 2$)$ and the significant positive relationships (Table 4 ) between sea urchin density and each of nitrate $\left(r^{2}=0.61, \mathrm{t}=3.07, \mathrm{P}<0.05\right)$, DIN $\left(r^{2}=0.57, \mathrm{t}=2.82\right.$, $\mathrm{P}<0.05)$ and reactive silicate $\left(r^{2}=0.53, \mathrm{t}=2.6, \mathrm{P}<0.05\right)$. High nitrogen levels are reported to enhance the egg quality, larval survival and somatic growth of sea urchins in controlled feeding studies (de Jong-Westman et $a l ., 1995)$. Walker and Ormond (1982) found that the population density of Diadema setosum was higher in the sewage area (mean $6.6 \mathrm{~m}^{-2}$ ) than in control area (mean $2.1 \mathrm{~m}^{-2}$ ) at Aqaba, Red Sea. This is consistent with the present results at location II, where Diadema setosum was the dominant sea urchin in this sewage-impacted area. Diadema setosum and Echinometra mathaei were the most abundant sea urchins in the area of investigation and considered as important coral bioeroders and algal grazers, feeding on the non-living component of reef framework as well as on living coral surfaces (Ormond, 1982). Bioerosion by urchins includes excavation and all abrasive activities including spine abrasion, which result in the forming of cavities and burrows, reducing overall reef consolidation (Kiene and Hutchings, 1994). Bioerosion also weakened the bases of large massive coral colonies, making them less resistant to storms and exposed to dislodgement and increased the susceptibility of corals to some diseases (Bak, 1994; ISRS, 2004). The present results in table 4 reinforce the damaging influence of sea urchin on reef-building corals, where raised sea urchin density significantly enhanced the dead coral cover $\left(r^{2}=0.56, t=2.74, P<0.05\right)$ and obviously lowered the live hard coral cover $\left(r^{2}=0.43, t=-2.12, P>0.05\right)$. As a result, higher sea urchins density (Echinometra mathaei) observed at location III (south Ain Al-Sukhna) might be strongly contributing to the greatest dead coral cover (23.28\%) and lowest live hard coral cover (35.26\%) found in this site (Table 2). In location II (Hurghada), it was common to find large healthy colonies of massive corals that are completely hollow, or partially hollow because their skeleton have been completely or partially eroded by Diadema setosum, leaving a thin shell of carbonate and living tissue. This is in accordance with the findings of Glynn (1997). In Negril Marine Park, Jamaica, Lapointe and Thacker (2002) reported that the lowest cover of both hard corals and calcareous macroalgae (calcifiers) coincided 
with the highest density of sea urchins (particularly echinoids) on shallow and deep reefs, especially in Long Bay.

Exceeding nutrient concentrations above the critical threshold levels for eutrophication (Bell 1992; Lapointe et al. 1993) can enhance the growth rates and abundance of macroalgae, which compete with corals for substrate space (Genin et al., 1995; Dubinsky and Stambler, 1996; Lapointe et al., 1999). The proliferated macroalgae compete with corals via combinations of overshading, overgrowth, smothering, abrasion of colony edges, preemption of coral larvae settlement space and sediment trapping ability (Birkeland, 1977; Pastorak and Bilyard, 1985; Tomascik and Sander, 1987b; Hodgson, 1990; Jompa and McCook, 2002). This is another indirect way by which nutrient enrichment may adversely affect corals and coral reef ecosystems. There has been considerable, recent controversy over the relative importance of nutrient enrichment (bottomup hypothesis) and herbivory (top-down hypothesis) factors in controlling the changes in growth and abundance of algae. According to the bottomup hypothesis, excess nutrient supply (eutrophication) results in an increased growth and abundance of benthic algae (e.g. Lapointe, 1997, 1999; Lapointe et al., 1997; Schaffelke, 1999; Lapointe and Thacker, 2002), leading to overgrowth of corals and subsequent reef degradation (Smith et al., 1981; Pastorak and Bilyard, 1985; Bell, 1992). The topdown hypothesis argues that algal biomass is predominantly controlled by herbivore consumption (e.g. Hughes et al., 1999; Aronson and Percht, 2000 ). According to this view, the declining levels of herbivory caused by reduced herbivore abundance as a result of overfishing and diseases is a reason of increased algal abundance and subsequent competitive overgrowth of corals (Thacker et al., 2001). Results of the present study (Tables 2, 4) pointed out that nutrient enrichment and increased TSM were the important synergistic factors responsible for increased growth rates and standing crops of macroalgae (fleshy and turf algae) on reefs of the Northern Red Sea (Riegl and Velimirov, 1991; Ali, 2001). The cover of macroalgae was significantly increased with the elevated concentrations of DIN $\left(r^{2}=0.93, \mathrm{t}=9.07, \mathrm{P}<0.001\right)$, ammonia $\left(r^{2}=0.55\right.$, $\mathrm{t}=2.69, \mathrm{P}<0.05)$ and TSM $\left(r^{2}=0.83, \mathrm{t}=5.46, \mathrm{P}<0.01\right)$. Reactive silicate also considerably contributed to increased macroalgal cover $\left(r^{2}=0.46, \mathrm{t}=\right.$ $2.27, \mathrm{P}>0.05$ ). Thus, these observations are in agreement with the predictions of bottom-up hypothesis. In addition, the higher concentrations of DIN, nitrate, and ammonia recorded at locations II and III (Table 1) together with greater density of sea urchins Diadema 
setosum and Echinometra mathaei, the main grazers (herbivores), dismiss the top-down control. Therefore, the present study confirms the key role of nutrient enrichment and TSM in controlling the abundance and growth rates of macroalgae. Walker and Ormond (1982) found that increased algal standing crop in the sewage area at Aqaba, Red Sea, was not due to the absence of grazers (Diadema setosum) but presumed due to increased nutrient levels associated with sewage discharge, since Diadema setosum showed a higher population density $\left(6.6 \mathrm{~m}^{-2}\right)$ in this sewage area. Eutrophication due to anthropogenic activities throughout the past three decades in the Northern Red Sea has allowed macroalgae to overgrow, overshade and smother many massive hermatypic corals (Riegl and Velimirov, 1991; Genin et al., 1995). Dubinsky and Stambler (1996); Lapointe (1999) reported that increases in nutrient availability can dramatically increase macroalgal growth rates and biomass, and remove the competitive advantage of zooxanthellate corals over seaweeds. However, It has been assumed that the relative importance of nutrients and herbivory in controlling benthic algal abundance will depend on circumstances such as location, herbivore regimes, background nutrient supplies and disturbance regimes (McCook, 1999). Apart from the current debate over the relative importance of nutrient enrichment and herbivory in controlling benthic algal abundance, it is important to recognize that both bottom-up and top-down perspectives assume that increased algal abundance will lead to decreased coral abundance by altering the competitive balance between algae and corals in the favor of algae (McCook, 1999; McCook et al., 2001a). Thus, competition between corals and algae is a critical step in either hypothesis (model) of reef degradation. It was observed that red algae (Rhodophyta) were typically abundant on undisturbed oligotrophic reefs (Littler et al., 1987) and scarce in the reefs with prolonged elevated nutrient (Table 5). On the other hand, green algae (Chlorophyta) and brown algae (Phaeophyta) were the dominant algae in the nutrient-disturbed reefs. This is consistent with the results of Riegl and Velimirov (1991) and Lapointe et al. (1997). Increased nutrient availability has resulted in overgrowth of corals by green alga Enteromorphia spp. in the Red Sea (Genin et al., 1995), while eutrophication from sewage was correlated with the dominance of macroalga Dictyosphaeria cavernosa in Kaneohe Bay, Hawaii (Smith et al., 1981).

Nutrient enrichment can also increase the phytoplankton biomass (as indicated by chlorophyll $a$ concentration), which in turn increases the 
water turbidity and therefore decrease the amount of light available to corals (Bell and Elmetri, 1995; Genin et al., 1995). Thus, enhanced phytoplankton biomass has been implicated in the reduction of light available to zooxanthellae photosynthesis and subsequent corals calcification and growth rates (Kinsey, 1988). The suggested threshold concentration of chlorophyll $a$ for eutrophication is in the range of $0.3-0.5$ $\mu \mathrm{g} \mathrm{l}^{-1}$ (Bell, 1991, 1992). The mean concentration of chlorophyll $a$ that exceeded the critical threshold range was obtained at location II $(0.59 \mu \mathrm{g}$ $\mathrm{I}^{-1}$ ), while the values recorded at locations III, V, VI and VIII (Table I) were in the range of threshold level. In sites I, IV and VII, the concentrations of chlorophyll $a$ were less than the threshold range. Table 3 displayed that chlorophyll $a$ concentrations were significantly $(\mathrm{P}<0.05)$ increased with enlianced concentrations of DIN and silicate $\left(r^{2}=0.66, t=\right.$ 3.43 and $r^{2}=0.54, \mathrm{t}=2.67$, respectively). Chlorophyll $a$ concentrations were also positively correlated with concentrations of ammonia $\left(r^{2}=\right.$ $0.46, t=2.25, P>0.05$ ). Consequently, the higher levels of DIN and ammonia at locations II and VI as well as the elevated concentrations of DIN and silicate at location III, due to terrestrial nutrient runoff, might contribute to the increased phytoplankton biomass in these areas. In the Negril Marine Park, Jamaica, chlorophyll a concentrations were above values typical of Caribbean "blue water" $\left(<0.1 \mu \mathrm{g} \mathrm{l}^{-1}\right)$ and indicated significant increase in phytoplankton biomass and associated light attenuation due to terrestrial nutrient runoff (Lapointe and Thacker, 2002).

It was observed that many nearshore reef-building corals at locations III and VI have been displaced by soft corals (Table 2), particularly Sarcophyton spp., Lithophyton spp., Lobophytum spp. and Sinularia spp. The possible explanation for this observation is that soft corals have greater resistance to increased nutrient levels than reefbuilding corals (hermatypic) which are sensitive to clianges in water quality (Benayahu, 1985; Wilkinson, 1996). So, they are not sensitive indicator of nutrient induced stress in coral reefs (Fleury et al., 2000). Sarcophyton species are common on inshore reefs of the Great Barrier Reef and so are able to accommodate a wide range of nutrient conditions without adverse effects (Koop et al., 2001). Smith et al. (1981) noticed that after increase of macroalgae, as a consequence of increased nutrient input, the benthic community structure was shifted away from corals towards filter feeders, such as soft corals, bryozoans, sponges, tunicates,.........etc.). 
Therefore, it is recommended that a water quality monitoring programme and an integrated sustainable coastal management plan should. be started to conserve the marine ecosystems along the Red Sea coast of Egypt, particularly the sensitive ecosystems like coral reefs and seagrasses from increasing land-based sources of pollution and anthropogenic impacts. These ecosystems harbour enormous number of fish species and economically important invertebrates.

\section{REFERENCES}

Adams, V. D. (1990). Water and wastewater examination manual. Lewis Publications, Michigan 48118, USA.

Ali, A. A. M. (2001). Human impacts on coral reefs along the Egyptian Red Sea coast. Ph. D. Thesis, University of Zagazig, Egypt.

APHA (American Public Health Association, 1995). Standard methods for the examination of water and wastewater. 19th edition, Washington.

Aronson, R. B. and Precht, W. F. (2000). Herbivory and algal dynamics on the coral reef at Discovery Bay, Jamaica. Limnol. Oceanogr., 45 (I): 251-255.

Bak, R. P. M. (1994). Sea urchins bioerosion on coral reefs: place in the carbonate budget and relevant variables. Coral Reefs, 13:99-103.

Bell, P. R. F. (1991). Status of eutrophication in the Great Barrier Reef lagoon. Mar. Pollut. Bull., 23: 89-93.

Bell, P. R. F. (1992). Eutrophication and coral reefs-some examples in the Great Barrier Reef lagoon. Water Res., 26 (5): 553-568.

Bell, P. R. F. and Elmetri, I. (1995). Ecological indicators of large-scale eutrophication in the Great Barrier Reef lagoon. Ambio, 24 (4): 208-215. 
IMPACT OF WATER QUALTTY DETERIORATION ON CORAL 131 REEF COMMUNITY STRUCTURE IN THE NORTHERN RED SEA

Beltagy, A. I. (1983). Hydrography of the Red Sea waters near AlGhardaqa. Bull. Instit. Oceanogr. Fish., Egypt, 9: 69-77.

Benayahu, Y. (1985). Faunistic composition and patterns in the distribution of soft corals (Octocorallia: Alcyonacea) along the coral reefs of Sinai Peninsula. Proc. 5th Int. Coral Reef Symp., Tahiti, 6 : 255-260.

Birkeland, C. (1977). The importance of rate of biomass accumulation in early successional stages of benthic communities to the survival of coral recruits. Proc. 3rd Int. Coral Reef Symp., Miami, $I: 15-21$.

Bryant, D.; Burke, L.; McManus, J. and Spalding. M. (1998). Reefs at risk. World Resources Institute, Library of Congress Catalog Card No. 98-86375, USA, pp. 8-34.

Cortes, J. N. and Risk, M. J. (1985). A reef under siltation stress: Cahuita, Costa Rica. Bull. Mar. Sci., 36 (2): 339-356.

de Jong-Westman, P.-Y. Q.; March, B. E. and Carefoot, T. H. (1995). Artificial diets in sea urchin culture: Effects of dietary protein level and other additives on egg quality, larval morphometrics, and larval survival in the green sea urchin, Strongylocentrotus droebachiensis. Can. J. Zool., 73: 2080 - 2090.

Dodge, R. E.; Logan, A. and Antonius, A. (1982). Quantitative reef assessment studies in Bermuda: A comparison of methods and preliminary results. Bull. Mar. Sci., 32 (3): 745-760.

Dodge, R. E. and Vaisnys, J. R. (1977). Coral populations and growth patterns: responses to sedimentation and turbidity associated with dredging. J. Mar. Res., 35: 715-730.

Dubinsky, Z. and Stambler, N. (1996). Marine pollution and coral reefs. Global Change Biol. 2: 511 - 526. 
Edinger, E: N.; Jompa, J.; Limmon, G. V.; Widjatmoko, W. and Risk, M. J. (1998). Reef clegradation and coral biodiversity in Indonesia: effects of Land-based pollution, destructive fishing practices and changes over time. Mar. Pollut. Bull. 36: 617 - 630.

EIMP (Environmental Information and Monitoring Program, 2004). Annual report of environmental data from coastal areas of the Suez Gulf, Aqaba Gulf and Red Sea proper during 2005. EEAA, DANIDA and NIOF, pp. 164.

Endean, R. (1976). Destruction and recovery of coral reef communities. In: Jones, O. A. \& Endean, R. (eds.) Biology and geology of coral reefs, Vol. III: Biology 2. Academic press, London.

Fahmy, M. A. (2001). Preliminary study on the hydrochemistry of the Egyptian coastal w'ater of Aqaba Gulf as a unique ecosystem during year 2000. Bull. Nat. Inst. Oceanogr. Fish., A. R. E. 27: 95-112.

['crier-Pages, C., Gattuso, J. -P., Dallot, S. and Jaubert, J. (2000). Effects of nutrient enrichment on growth and photosynthesis of zooxanthellate coral Stylophora pistillata. Coral Reefs 19: 103-113.

Fleury, B. J.; Coll, J. C.; Tentori, E.; Duquesne, S. and Figueiredo, L. (2000). Effect of nutrient enrichment on the complementary (secondary) metabolite composition of the soft coral Sarcophyton ehrenbergi (cnidaria: Octocorallia: Alcyonacea) of the Great Barrier Reef. Mar. Biol., 136: 63-68.

Furnas, M. J. (1991). Nutrient status and trends in waters of the Great Barrier Reef Marine Park. In: Yellowlees, D. (ed.) Land uses pattern and nutrient loadings of the Great Barrier Reef Region, James Cook University, Townsville, pp. 162-179.

Genin, A.; Lazar, B. and Brenner, S. (1995). Vertical mixing and coral death in the Red Sea following the eruption of Mount Pinatubo. Nature, 377: 507-510. 
Glynn, P. W. (1997). Bioerosion and coral reef growth: A. dynamic balance. In: Birkeland, C. (ed.) Life and death of coral reefs. Chapman \& Hall, New York, 68pp.

Grigg, R. W. and Dollar, S. J. (1990). Natural and anthropogenic disturbance on coral reefs. In: Dubinsky, Z. (ed.) Coral Reefs. Elsevier Science Publishers B. V., Amsterdam, Netherlands, pp. 439-452.

Harrison, P. L. and Ward, S. (2001). Elevated levels of nitrogen and phosphorus reduce fertilization success of gametes from scleractinian reef corals. Mar. Biol. 139: 1057-1068.

Hodgson, G. (1990). Sediment and the settlement of larvae of the reef coral Pocillopora damicornis. Coral reefs, 9: 41-43.

Hodgson, G. (1999). A global assessment of human effects on coral reefs. Mar. Pollut. Bull. 38: 345 - 355.

Hughes, T. P.; Szmant, A. M.; Steneck, R.; Carpenter, R. and Miller, S. (1999). Algal blooms on coral reefs: what are causes Limnol. Oceanogr., 44: $1583-1586$.

Hunte, W. and Wittenberg, M. (1992). Effects of eutrophication and sedimentation on juvenile corals II: Settlement. Mar. Biol., 114: 625-631.

ISRS (2004). The effects of terrestrial runoff of sediments, nutrients and other pollutants on coral reefs. Briefing paper 3, International Society for Reef Studies, $18 \mathrm{pp}$.

Johannes, R. E. (1975). Pollution and degradation of coral reef communities. In: Wood, E. J. F. \& Johannes, R. E. (eds.) Tropical marine pollution. Elsevier Scientific Publishing Company, New York, USA, pp. 13-51. 
Jompa, J. and McCook, L. J. (2002). The effects of nutrients and herbivory on competition between a hard coral (Porites cylindrica) and a brown alga (Lobophora variegata). Limnol. Oceanogr. 47(2): 527-534.

Kiene, W. E. and Hutchings, P. A. (1994). Bioerosion experiments at Lizard Island, Great Barrier Reef. Coral Reefs, 13:91 - 98.

Kinsey, D. W. (1988). Coral reef system response to some natural and anthropogenic stresses. Galaxea, 7: 113-128.

Koop, K.; Booth, D.; Broadbent, A.; Brodie, J.; Bucher, D.; Capone, D., Coll, J.; Dennison, W.; Erdmann, M.; Harrison, P.; HoeghGuldberg, O.; Hutchings, P.; Jones, G. B.; Larkum, A. W. D., O'Neil, J.; Steven, A.; Tentori, E.; Ward, S.; Williamson, J. and Yellolees, D. (2001). ENCORE: The effects of nutrient enrichment on coral reefs. Synthesis of results and conclusions. Mar. Pollut. Bull., 42 (2): 91-120.

Lapointe, B. E. (1997). Nutrient thresholds bottom-up control of macroalgal blooms on coral reefs in Jamaica and southeast Florida. Limnol. Oceanogr. 42: 1119 - 131.

Lapointe, B. E. (1999). Simultaneous top-down and bottom-up forces control macroalgal blooms on coral reefs. Limnol. Oceanog., 44 (6): $1586-1592$.

Lapointe, B. E.; Littler, M. M. and Littler, D. S. (1993). Modification of benthic community structure by natural eutrophication: The Belize Barrier Reef. Proc. 7th Int. Coral Reef Symp., Guam, 1: 323-334.

Lapointe, B. E.; Littler, M. M. and Littler, D. S. (1997). Macroalgal overgrowth of fringing coral reefs at Discovery Bay, Jamaica: Bottom-up versus Top-down control. Proc. 8th Int. Coral Reef Symp. Jamaica, 1: 927-932. 
IMPACT OF WATER QUALITY DETERIORATION ON CORAL 135

REEF COMMUNITY STRUCTURE IN THE NORTHERN RED SEA

Lapointe, B. E. and Thacker, K. (2002). Community-based water quality and coral reef monitoring in the Negril Marine Park, Jamaica: Landbased nutrient inputs and their ecological consequences. In: Porter, W. J. \& Porter, K. G. (eds.) The Everglades, Florida Bay, and coral reefs of the Florida Keys an ecosystem source book. CRC Press, London, pp. 939-963.

Lewis, J. B. (1977). Processes of organic production on coral reefs. Biol. Rev. Cambridge Philos. Soc., 52: $305-347$.

Lipp, E. K.; Jarrell, J. L.; Griffin, D. W.; Lukasik, J.; Jacukiewicz, J. and Rose, J. B. (2002). Preliminary evidence for human fecal contamination in corals of the Florida Keys, USA. Mar. Pollut. Bull. 44: 666-670.

Littler, M. M; Taylor, P. R.; Littler, D. S.; Sims. R. H. and Norris, .I. N. (1987). Dominant macrophyte standing stocks, productivity and community structure on a Belizean Barrier Reef. Atoll. Res. Bull., 302: I -24.

McCook, L. J. (1999). Macroalgae, nutrients and phase-shifts on coral reefs: scientific issue and management consequences for the Great Barrier Reef. Coral Reefs, 18: $357-367$.

McCook, L. J.; Jompa, J. and Diaz-Pulido, G. (2001a). Competition between corals and algae on coral reefs: a review of available evidence and mechanisms. Coral Reefs, 19: 400-417.

Morcos, S. A. (1970). Physical and chemical oceanography of the Red Sea. Oceanogr. Mar. Biol., 8: 73-203.

Ormond, R. F. G. (1982). Report on the need for management and marine parks in the Egyptian Red Sea. Institute of Oceanography and Fisheries, Academy of Sciences, Cairo. 
Parsons, T. R. Maita, Y. and Lalli, C. M. (1984). A manual of chemical and biological methods for seawater analysis. Pergamon Press, Oxford

Pastorak, R. A. and Bilyard, G. R. (1985). Effects of sewage pollution on coral reef communities. Mar. Ecol. Prog. Ser., 21: 175-189.

Riegl, B. and Velimirov, B. (1991). How many damaged corals in Red Sea reef systems? A quantitative survey. Hydrobiologia, 216/217: 249-256.

Pielou, E. G. (1966). The measurement of diversity in different types of biological collections. J. Theoret. Biol., 13: 131-144.

Rogers, C. S. (1979). The effects of shading on coral reef structure and function. J. Exp. Mar. Biol. Ecol., 41: 269-288.

Rogers, C. S.; Garrison, G.; Grober, R.; Hillis, Z. M. and Franke, M. A. (1994). Coral reef monitoring manual for the Caribbean and Western Atlantic. National Park Service, Virgin Island National Park.

Schaffelke, B. (1999). Short-term nutrient pulses as tools to assess responses of coral reef macroalgae to enhanced nutrient availability. Mar. Ecol. Prog. Ser., 182: 305-310.

Scheer, G. (1984). The distribution of reef corals in the Indian Ocean with a historical review of its investigation. Deep Sea Res., A 31: 885900 .

Shannon, C. E. and Weaver, W. (1948). The mathematical theory of communication. University of Illinois Press, Urbana, Illinois.

Sheppard, C. R. C. (1988). Similar trends, different causes: Responses of corals to stressed environments in Arabian Seas. Proc. 6th Int. Coral Reef S j,ymp., Australia, 3: 297-302. 
Smith, S. V.; Kimmerer, W. J.; Laws, E. A.; Brock, R. E. and Walsh, T. W. (1981). Kaneohe Bay sewage diversion experiment: Perspectives on ecosystem responses to nutritional perturbation. Pac. Sci., 35: 279-402.

Thacker, R. W.; Ginsburg, D. W. and Paul V. J. (2001). Effects of herbivore exclusion and nutrient enrichment on coral reef macroalgae and cyanobacteria. Coral Reefs 19: 318-329.

Tomascik, T. and Sander, F. (1985). Effects of eutrophication on reefbuilding corals. I. Growth rate of the reef-building coral Montastrea annularis. Mar. Biol., 87: 143-155.

Tomascik, T. and Sander. F. (1987a). Effects of eutrophication on reefbuilding corals. Il. Structure of scleractinian coral communities on fringing reefs, Barbados, West Indies. Mar. Biol., 94: 53-75.

Tomascik, T. and Sander, F. (1987b). Effects of eutrophication on reefbuilding corals. III. Reproduction of the reef-building coral Porites porites. Mar. Biol., 94: 77-94.

van Woesik, R.; Tomascik, T. and Blake, S. (1999). Coral assemblages and physico-chemical characteristics of the Whitsunday Islands: evidence of recent community changes. Marine and Freshwater Research 50: $427-440$.

Vine, P. (1986). Red Sea invertebrates. Immel Publishing, Ely house, 37 Dover Street, London, WIX 3RB.

Walker, D. I. and Ormond, R. F. G. (1982). Coral death from sewage and phosphate pollution at Aqaba, Red Sea. Mar. Pollut. Bull., 13 (1): 21-25.

Webster, C. and Smith, S. R. (2002). Reduced juvenile coral populations on reefs affected by sewage discharge in Bermuda. Proc. 9th Int. Coral Reef Symp., Bali, Indonesia. 
Wilkinson, C. (1996). Global change and coral reefs: Impacts on reefs, economics and human cultures. Global Change Biol., 2: 547-558.

Wittenberg, M. and Hunte, W. (1992). Effects of eutrophication and sedimentation on juvenile corals. I. Abundance, mortality and community structure. Mar. Biol., 112: 131-138. 
IMPACT OF WATER QUALITY DETERIORATION ON CORAL 139 REEF COMMUNTTY STRUCTURE IN THE NORTHERN RED SEA

Table 1. Mean annual values of temperature, pH, salinity, dissolved oxygen (DO), Chemical oxygen demand (COD), biological oxygen demand (BOD), nitrite, nitrate, ammonia, dissolved inorganic nitrogen (DIN, nitrite + nitrate + ammonia), reactive phosphate. reactive silicate, chlorophyll $a$, total suspended matter (TSM) and transparency in seawater at the investigated locations.

\begin{tabular}{|c|c|c|c|c|c|c|c|c|}
\hline \multirow{2}{*}{ Parameter } & \multicolumn{8}{|c|}{ Locations } \\
\hline & 1 & II & III & IV & $\mathbf{v}$ & VI & VII & VIII \\
\hline Temperature $\left({ }^{\circ} \mathrm{C}\right)$ & 23.56 & 23.58 & 22.48 & 22.81 & 23.23 & 23.05 & 22.68 & 23.03 \\
\hline $\mathrm{pH}$ & 8.18 & 8.22 & 8.17 & 8.22 & 8.21 & 8.21 & 8.17 & 8.20 \\
\hline Salinity $(p p r)$ & 41.05 & 41.49 & 41.78 & 40.39 & 41.26 & 40.98 & 40.07 & 40.78 \\
\hline Dissolved oxygen ( $m g l^{-1}$ ) & 7.37 & 7.82 & 8.36 & $8.1^{\circ}$ & 8.71 & 8.16 & 7.56 & 8.76 \\
\hline $\operatorname{COD}\left(\mathrm{mg} \mathrm{l}^{-1}\right)$ & 2.07 & 2.12 & 2.16 & 2.16 & 1.62 & 1.53 & 1.36 & 1.56 \\
\hline $\mathrm{BOD}\left(\mathrm{mg} \mathrm{l}^{-1}\right)$ & 2.83 & 2.53 & 3.18 & 2.39 & 1.80 & 1.87 & 1.71 & 2.5 \\
\hline Nitrite $\left(\mathrm{NO}_{2}-\mathrm{N}, \mu \mathrm{M}\right)$ & 0.04 & 0.11 & 0.28 & 0.11 & 0.19 & 0.21 & 0.03 & 0.12 \\
\hline Nitrate $\left(\mathrm{NO}_{3}-\mathrm{N}, \mu \mathrm{M}\right)$ & 0.33 & 0.43 & 5.82 & 0.52 & 0.63 & 0.75 & 0.54 & 0.36 \\
\hline mmonia $\left(\mathrm{NH}_{\xi}-\mathrm{N}, \mu \mathrm{M}\right)$ & 0.60 & 2.61 & 0.73 & 0.64 & 0.77 & 1.27 & 0.57 & 0.44 \\
\hline $\operatorname{DNN}(\mu \mathrm{M})$ & 0.97 & 3.15 & 2.83 & 1.27 & 1.59 & 2.23 & 1.14 & 0.92 \\
\hline hosphate $\left(\mathrm{PO}_{4}-\mathrm{P}, \mu \mathrm{M}\right)$ & 0.03 & 0.05 & 0.06 & 0.04 & 0.01 & 0.02 & 0.01 & 0.01 \\
\hline illicate $\left(\mathrm{SiO}_{\mathbf{A}}-\mathrm{Si}, \mu \mathrm{M}\right)$ & 1.30 & 2.46 & 4.07 & 2.18 & 2.77 & 3.08 & 0.98 & 2.03 \\
\hline rophyll $a\left(C h l-a, \mu \mathrm{g} \mathrm{l}^{-1}\right)$ & 0.17 & 0.59 & 0.48 & 0.21 & 0.41 & 0.44 & 0.14 & 0.4 \\
\hline $\operatorname{TSM}\left(\mathrm{mg}\left[^{-1}\right)\right.$ & 6.64 & 8.10 & 8.17 & 5.22 & 6.51 & 6.15 & 5.56 & 6.16 \\
\hline ansparency (in meter) & 7.50 & 7.00 & 6.00 & 11.50 & 10.00 & 10.50 & 11.40 & I I \\
\hline
\end{tabular}


Table 2. Percent cover of common hard coral species and coral community variables at the investigated locations. Common species were defined as these accounted for $>2 \%$ of the total cover in at least 2 sites.

\begin{tabular}{|c|c|c|c|c|c|c|c|c|}
\hline \multirow[b]{2}{*}{ Common species } & \multicolumn{8}{|c|}{ Locations } \\
\hline & 1 & II & 111 & IV & $\mathrm{v}$ & VI & VII & VIII \\
\hline Stylophora pistillasa & 1.40 & 2.05 & 5.26 & 1.50 & 0.60 & 1.64 & & 0.31 \\
\hline Pocillopora damicornis & 7.10 & 2.03 & & 0.12 & & 3.91 & 0.50 & 2.65 \\
\hline Poclllopora verrucosa & & & & & 3.34 & 2.73 & & 1.40 \\
\hline Acropora hyacinthus & 3.20 & 2.26 & & 15.29 & 7.08 & 5.91 & 9.50 & 2.50 \\
\hline Acropora valida & 2.50 & 2.07 & 0.43 & & & & & \\
\hline Acropora humilis & 0.33 & 0.77 & 0.27 & 6.50 & 0.40 & 6.18 & $\begin{array}{c}2.0 \\
0 \\
\end{array}$ & 2.95 \\
\hline Acropora hemprichi & 3.60 & 1.68 & 1.47 & 9.34 & 0.84 & & 0.50 & 0.50 \\
\hline Aclopora pharaonis & & 1.75 & 6.39 & 7.50 & & & & \\
\hline Acropora nobilis & 2.33 & 2.11 & 0.22 & 0.17 & & & & \\
\hline Acropora forskali & & 2.10 & 2.20 & & & & & \\
\hline Acropora corymbosa & 2.40 & 0.13 & & 2.30 & 0.20 & 0.91 & 0.40 & 1.30 \\
\hline Acropora eurystoma & & 0.37 & & 0.59 & 2.24 & & 3.00 & \\
\hline Goniopora columna & 0.16 & 2.35 & & 0.42 & & & 5.00 & \\
\hline Porites solida & 4.20 & 3.22 & 2.44 & & & & 2.25 & 13.25 \\
\hline Porites Ittea & 1.48 & 2.22 & 2.28 & & 3.00 & 8.64 & 10.30 & 10.00 \\
\hline Favia stelligera & 0.49 & 0.50 & & 0.63 & 2.42 & 5.55 & & \\
\hline Faviles complanala & & 0.71 & & & 0.44 & & 4.00 & 5.00 \\
\hline Faviles flexuosa & 0.85 & 0.68 & & 0.63 & & & 2.05 & 2.30 \\
\hline Goniasirea retiformis & & 1.60 & & & 0.28 & 1.73 & 2.00 & 2.90 \\
\hline Platygyra deadalea & & 0.69 & & 2.71 & & 2.36 & & \\
\hline Platygyra lameflina & & 0.72 & 0.65 & & 2.20 & 0.45 & 5.00 & 2.20 \\
\hline Leptoria phrygia & & 0.55 & & & 5.92 & 2.73 & & 12.00 \\
\hline Echinopora gemmacea & & 0.89 & 1.73 & 1.67 & 2.40 & 3.27 & & 0.60 \\
\hline Echinopora fruticulosa & 3.50 & 0.26 & 2.06 & & & & & \\
\hline Galarea foscicularis & & 1.60 & 2.45 & 2.13 & & & & \\
\hline Lobophyllia corymbosa & & 2.63 & 1.60 & & & 0.91 & 9.50 & \\
\hline Millepora dichoroma & 4.90 & 1.96 & & & 1.88 & 1.64 & & 6.75 \\
\hline Millepora platyphylla & 1.07 & 0.44 & & & 6.26 & 5.45 & & 0.30 \\
\hline \multicolumn{9}{|l|}{ Coral community variables } \\
\hline Live hard coral cover (\%) & 46.03 & 49.30 & 35.26 & 53.93 & 40.62 & 54.92 & 63.55 & 67.10 \\
\hline
\end{tabular}


IMPACT OF WATER QUALITY DETERIORATION ON CORAL 141 REEF COMMUNITY STRUCTURE IN THE NORTHERN RED SEA

\begin{tabular}{|l|c|c|c|c|c|c|c|c|}
\hline Soff coral cover (\%) & 5.84 & 8.76 & 18.33 & 12.24 & 3.20 & 14.99 & 4.50 & 13.50 \\
\hline Dead coral cover (\%) & 14.84 & 12.35 & 23.28 & 14.07 & 14.28 & 15.76 & 9.16 & 2.50 \\
\hline Percent cover of algae & 5.46 & 13.37 & 12.36 & 4.36 & 5.92 & 7.77 & 3.42 & 3.70 \\
\hline Bare subsiratum (\%) & 27.83 & 16.22 & 10.77 & 15.40 & 35.98 & 6.56 & 19.37 & 13.20 \\
\hline Hard coral density $\left(\# \mathrm{~m}^{-2}\right)$ & 8.90 & 9.66 & 4.70 & 5.26 & 4.72 & 9.64 & 10.11 & 3.35 \\
\hline Species diversity $\left(\mathrm{H}_{\mathrm{N}}\right)$ & 2.71 & 3.06 & 1.86 & 2.27 & 2.38 & 2.11 & 1.77 & 2.45 \\
\hline Pielou's Evenness index $(\mathrm{J})$ & 0.80 & 0.71 & 0.56 & 0.87 & 0.82 & 0.72 & 0.61 & 0.85 \\
\hline Sea urchin density $\left(\# \mathrm{~m}^{-2}\right)$ & 2.40 & 4.77 & 7.90 & 3.70 & 1.50 & 2.60 & 0.90 & 1.30 \\
\hline
\end{tabular}


Table 3. Statistical relationships between some of the different water quality parameters at the investigated locations. The relationships are significant at $P<0.05$. TSM: Total suspended matter, DIN: Dissolved inorganic nitrogen, BOD: Biological oxygen demand, COD: Chemical oxygen demand.

\begin{tabular}{|l|ccc|}
\hline \multicolumn{1}{|c|}{$\begin{array}{c}\text { Regression equations } \\
(\mathrm{Y}=\mathrm{a}+\mathrm{bx})\end{array}$} & $r^{2}$ & t value & $\mathbf{P}$ \\
\hline TSM $=3.619+1.253 \mathrm{BOD}$ & 0.37 & 1.884 & 0.1090 \\
$\mathrm{TSM}=4.819+0.99 \mathrm{DIN}$ & 0.64 & 3.260 & 0.0170 \\
$\mathrm{TSM}=5.084+0.627$ silicate & 0.33 & 1.720 & 0.1360 \\
$\mathrm{TSM}=4.829+4.887$ chlorophyll $a$ & 0.54 & 2.680 & 0.0370 \\
TSM $=4.77+0.254$ algal cover $(\%)$ & 0.83 & 5.460 & 0.0016 \\
Chlorophyll $a=0.087+0.152 \mathrm{DIN}$ & 0.66 & 3.430 & 0.0140 \\
Chlorophyll $a=0.208+0.154$ ammonia & 0.46 & 2.250 & 0.0660 \\
ChIorophyll $a=0.068+0.122$ silicate & 0.54 & 2.670 & 0.0370 \\
Silicate $=1.270+1.618$ nitrate & 0.63 & 3.210 & 0.0180 \\
Silicate $=0.925+0.813$ DIN & 0.51 & 2.500 & 0.0450 \\
Transparency $=17.263-4.335$ COD & 0.44 & -2.180 & 0.0720 \\
Transparency $=16.692-3.117 \mathrm{BOD}$ & 0.56 & -2.750 & 0.0334 \\
Transparency $=12.256-1.642$ DIN & 0.43 & -2.110 & 0.0800 \\
Transparency $=21.731-1.884$ TSM & 0.86 & -6.050 & 0.0009 \\
\hline
\end{tabular}


IMPACT OF WATER QUALITY DETERIORATION ON CORAL 143 REEF COMMUNITY STRUCTURE IN THE NORTHERN RED SEA

Table 4. Stastistical relationships between water quality parameters and coral community variables at the investigated locations. The relationships are significant at $\mathrm{P}<0.05$. HCOV: live hard coral cover, DCOV: dead coral cover, Udensity: sea urchin density (\# of urchins $\mathrm{m}^{-2}$ ).

\begin{tabular}{l|ccc|}
\hline \multicolumn{1}{c|}{$\begin{array}{c}\text { Regression equations } \\
(\mathrm{Y}=\mathrm{a}+\mathrm{bx})\end{array}$} & $\boldsymbol{R}^{2}$ & $\mathbf{t}$ value & $\mathbf{P}$ \\
\hline HCOV $=667.416-15.035$ salinity & 0.6 & -3.030 & 0.0230 \\
HCOV $=86.389-19.232$ COD & 0.35 & -1.810 & 0.1200 \\
HCOV $=93.797-6.469$ TSM & 0.41 & -2.050 & 0.0860 \\
HCOV $=60.506-13.631$ nitrate & 0.37 & -1.880 & 0.1090 \\
HCOV $=67.46-6.835$ silicate & 0.39 & -1.940 & 0.1005 \\
HCOV $=17.134+3.653$ transparency & 0.54 & 2.670 & 0.0371 \\
HCOV $=60.949-3.067$ u-density & 0.43 & -2.120 & 0.0778 \\
DCOV $=-235.506+6.072$ salinity & 0.33 & 1.730 & 0.1340 \\
DCOV $=-4.225+9.605$ COD & 0.30 & 1.590 & 0.1620 \\
DCOV $=7.081+9.218$ nitrate & 0.57 & 2.820 & 0.0300 \\
DCOV $=6.474+3.862$ DIN & 0.32 & 1.690 & 0.1420 \\
DCOV $=4.022+3.925$ silicate & 0.43 & 2.120 & 0.0783 \\
DCOV $=28.735-1.651$ transparency & 0.37 & -1.890 & 0.1080 \\
DCOV $=6.895+.906$ algal cover & 0.35 & 1.800 & 0.1220 \\
DCOV $=7.318+1.903$ u-density & 0.56 & 2.740 & 0.0340 \\
Algal cover $(\%)=-14.432+3.272$ TSM & 0.83 & 5.460 & 0.0016 \\
Algal cover $(\%)=4.113+4.360$ nitrate & 0.30 & 1.600 & 0.1600 \\
Algal cover $(\%)=3.233+3.997$ ammonia & 0.55 & 2.690 & 0.0360 \\
Algal cover $(\%)=0.510+4.286$ DIN & 0.93 & 9.070 & 0.0001 \\
Algal cover $(\%)=.774+2.659$ silicate & 0.46 & 2.270 & 0.0640 \\
U-density $=-6.376+5.218$ COD & 0.57 & 2.820 & 0.0300 \\
U-density $=-4.503+3.248$ BOD & 0.54 & 2.650 & 0.0380 \\
U-density $=-7.117+1.562$ TSM & 0.53 & 2.580 & 0.0420 \\
U-density $=0.617+3.743$ nitrate & 0.61 & 3.070 & 0.0220 \\
U-density $=-0.414+2.013$ DIN & 0.57 & 2.820 & 0.0300 \\
U-density $=-0.904+1.712$ silicate & 0.53 & 2.600 & 0.0410 \\
\hline
\end{tabular}


Table 5. Occurrence and distribution of macroalgae at the investigated reef sites. $0=$ not found, $+=$ rare, $++=$ moderate, $++=$ frequent,$+++=$ abundant

\begin{tabular}{|l|c|c|c|c|c|c|c|c|}
\hline \multirow{2}{*}{ Macroalgae } & \multicolumn{7}{|c|}{ Locations } \\
\cline { 2 - 9 } & I & II & III & IV & V & VI & VII & VIII \\
\hline Phaeophyta & & & & & & & & \\
\hline Padina pavonia & + & ++++ & ++ & ++ & ++ & +++ & + & ++ \\
\hline Cysloseira myrica & ++ & +++ & +++ & +++ & ++ & +++ & ++ & ++ \\
\hline Turbinaria elatensis & ++ & $+\div++$ & ++ & +++ & ++ & ++ & + & + \\
\hline Colpomenia sinuosa & + & +++ & +++ & + & ++ & ++ & ++ & ++ \\
\hline Hydroclathrus clathratus & ++ & +++ & +++ & + & + & + & ++ & ++ \\
\hline Sargassum latijolium & ++ & ++++ & +++ & ++ & + & ++ & + & + \\
\hline Chlorophyta & & & & & & & & \\
\hline Caulerpa racemosa & 0 & ++++ & + & +++ & ++ & + & ++ & + \\
\hline Caulerpa serrulata & + & +++ & ++ & + & 0 & + & + & 0 \\
\hline Valonia ventricosa & 0 & 0 & + & + & 0 & 0 & 0 & 0 \\
\hline Ulva lactuca & + & ++++ & +++ & + & + & +++ & + & + \\
\hline Halmida tuna & ++ & ++++ & + & ++++ & +++ & ++ & ++ & + \\
\hline Dictyosphaeria spp. & + & ++++ & +++ & ++ & 0 & ++ & + & + \\
\hline Enteromorpha spp. & ++ & +++ & ++++ & ++ & ++ & +++ & + & ++ \\
\hline Rhodophyta & & & & & & & & \\
\hline Laurencia oblusa & ++++ & + & ++ & + & ++ & + & ++ & + \\
\hline Laurencia papilosa & +++ & + & + & + & ++ & + & ++ & ++ \\
\hline Hypmea valintae & ++ & + & + & ++ & ++ & + & + & + \\
\hline Galaxura oblongata & ++ & + & 0 & + & ++ & + & ++ & + \\
\hline Acanithophora spp. & ++ & + & 0 & + & 0 & 0 & 0 & 0 \\
\hline Jania spp. & + & + & + & + & + & + & + & 0 \\
\hline
\end{tabular}


IMPACT OF WATER QUALITY DETERIORATION ON CORAL 145 REEF COMMUNITY STRUCTURE IN THE NORTHERN RED SEA

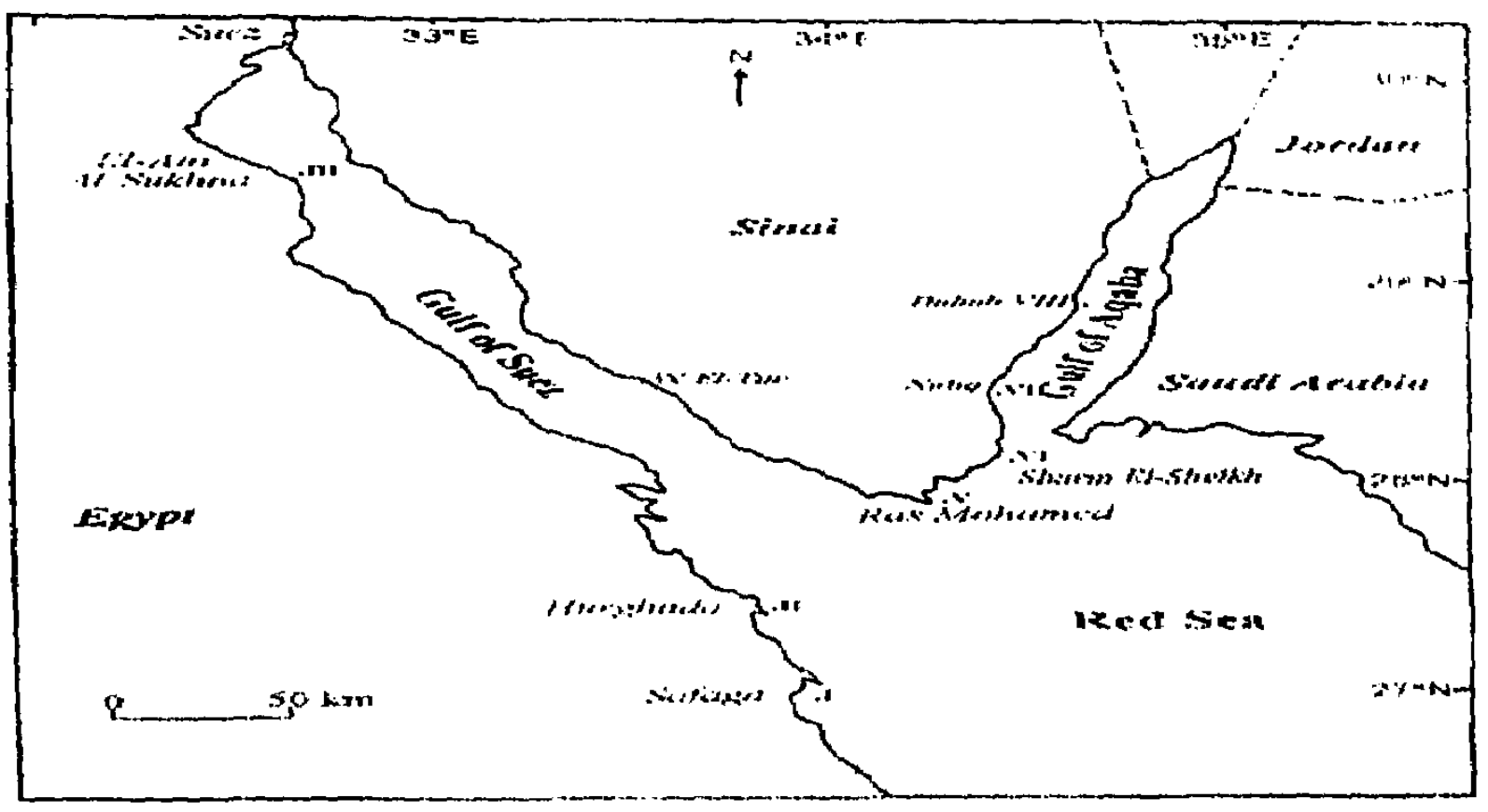

Fig. 1. Location map of the studied areas Locations: I=Safaga, II=Hurghada, III=South El-Ein Al-Sukhna, IV=EI-Tur, V=Ras Mohamed, VI=Sharm EI-Sheikh, VII =Nabq and VIII=Dahab. 